\title{
Switching off malignant mesothelioma: exploiting the hypoxic microenvironment
}

\author{
Noushin Nabavi1,2,3, Kevin L. Bennewith ${ }^{4,5}$, Andrew Churg5 ${ }^{1}$ Yuzhuo Wang ${ }^{2,3}$, Colin \\ C. Collins ${ }^{1,2}$, and Luciano Mutti ${ }^{6}$ \\ ${ }^{1}$ Laboratory for Advanced Genome Analysis, Vancouver Prostate Centre, BC, Canada \\ 2 Department of Urologic Sciences, University of British Columbia, BC, Canada \\ ${ }^{3}$ Department of Experimental Therapeutics, BC Cancer Agency, BC, Canada \\ ${ }^{4}$ Department of Integrative Oncology, BC Cancer Agency, BC, Canada \\ ${ }^{5}$ Department of Pathology and Laboratory Medicine, University of British Columbia, BC, Canada \\ ${ }^{6}$ Italian Group for Research and Therapy for Mesothelioma (GIMe) \& School of Environment and Life Sciences, University of \\ Salford, Manchester, United Kingdom
}

Correspondence to: Luciano Mutti, email: L.Mutti@salford.ac.uk

Colin C. Collins, email: ccollins@prostatecentre.com

Keywords: mesothelioma, hypoxia, metabolism, cell cycle, proteolysis, DNA damage, angiogenesis, solid tumors

Received: November 22, 2016 Accepted: December 31, 2016

Published: January 01, 2017

\section{ABSTRACT}

Malignant mesotheliomas are aggressive, asbestos-related cancers with poor patient prognosis, typically arising in the mesothelial surfaces of tissues in pleural and peritoneal cavity. The relative unspecific symptoms of mesotheliomas, misdiagnoses, and lack of precise targeted therapies call for a more critical assessment of this disease. In the present review, we categorize commonly identified genomic aberrations of mesotheliomas into their canonical pathways and discuss targeting these pathways in the context of tumor hypoxia, a hallmark of cancer known to render solid tumors more resistant to radiation and most chemo-therapy. We then explore the concept that the intrinsic hypoxic microenvironment of mesotheliomas can be Achilles' heel for targeted, multimodal therapeutic intervention.

Etiology and clinical manifestations of pleural mesotheliomas

Determining cancer etiology is an intricate process because evidence from genetics, cellular and molecular biology, as well as epidemiology and pathology must be integrated to gain a complete understanding of carcinogenicity [1]. Malignant mesotheliomas (derived from the Greek word mésos "middle" and oma "tumor") are rare cancers that originate from deregulated cellular proliferation of the mesoderm tissue lining the chest cavity, heart, lungs, the abdominal cavity, and the intraabdominal organs $[2,3]$. Scans made via computed tomography (CT), magnetic resonance image (MRI), or positron emission tomography (PET) are required to determine the location and extent of the disease [4]. More than $70 \%$ of the diagnosed cases are pleural, $20 \%$ are peritoneal, and less than $1 \%$ are pericardial or testicular types (as depicted in Figure 1A) [5-7].
The annual incidence of malignant mesothelioma in the United States alone is approximately 3,200 cases/year [8-11] and expected to rise worldwide [12]. The standard of care for all subtypes is chemotherapy such as cisplatin, pemetrexed, carboplatin, gemcitabine, or doxorubicin [1315]. In selected specialized centers, a multimodal approach is employed which includes radical cytoreductive surgery followed by radiation, chemotherapy, or targeted therapy. The sequences of treatments is guided by clinical tumor stage or patients' responses and depend on institutional experience [16-19]. Pleural mesothelioma has poor prognosis and patients have a median survival of 4-12 months post diagnosis when treated with chemotherapy [16]. In some cases, although debated, patients treated with multimodal neoadjuvant therapy followed by radical surgery and adjuvant/targeted therapy survive longer for approximately 24 months [20,21]. Recently, a metaanalysis showed that adjuvant radiotherapy does not improve survival [22]. 


\section{Pathogenesis and pathology of malignant mesotheliomas}

Mesothelioma is often caused by asbestos exposure $[23,24]$. However, in addition to the six fibers collectively called asbestos (the only mineral fibers used commercially in the 1970s), many other mineral fibers (e.g. erionite) that are naturally present in the environment can cause mesotheliomas [23, 25]. Persistent asbestos fiber pressure exerts a slow inflammatory, toxicity, and mutagenic response that can drive mesothelioma [26]. This occurs through altering characteristics attributed to promotion of cell proliferation, high mobility group box 1 (HMGB1) protein secretion [27, 28], sustained angiogenesis [29, 30], and alterations in the expression of redox dependent enzymes (e.g. MnSODs, SODs, catalases and oxygenase) [31-33]. Apart from domestic, environmental, and occupational exposure to asbestos or other carcinogenic mineral fibers, mesotheliomas can also be caused by inherited BAPl germline mutations [34]. Moreover carriers of germline $B A P 1$ mutations are at increased risk of mesothelioma when exposed to asbestos, including low doses that usually are not sufficient to cause cancer $[35,36]$. In addition, immune deficiency [37], chronic inflammation [38, 39], ionizing radiation [40, 41], and Simian virus 40 infection have been linked to development of mesothelioma [42-46]. Secondary mesothelioma malignancies may also develop after radiation therapy treatment of lymphomas [47, 48], breast [49], and testicular cancers [50].

To reliably diagnose and determine pathological subtypes of the disease, diagnostic surgery and biopsies of malignant tissues are needed so they can be subjected to further histological examination [51, 52]. Mesotheliomas are classically divided into three pathologic subtypes (i.e. epithelioid, sarcomatoid and biphasic) that are identified via histological and immunohistochemical examinations. These subtypes present distinct morphology and molecular properties (Figure 1B). Epithelioid tumors consist of rounded to cuboidal-shaped cells, account for 80 to $90 \%$ of cases [53, 54] and are associated with longer survival. Sarcomatoid forms comprise of $10-20 \%$ of diagnosed cases, have spindle shaped cells and give rise to bulky and aggressive tumors $[2,54]$. Biphasic tumor subtypes are as rare as the sarcomatoid and contain a mix of epithelioid and sarcomatous tissue [2, 54, 55].

\section{Genomic alterations of mesotheliomas amenable to targeted therapy}

Although the number of genomic aberrations in mesothelioma is typically lower when compared to other cancers [56], genome-wide profiling reveals enormous complexity in the underlying biology of these tumors [22, 57-65]. The lack of effective therapies and development of resistance is exacerbated by inter and intra-tumor genomic heterogeneities. Genomic aberrations include aneuploidies, point mutations, as well as numerous chromosomal rearrangements that result in deletions, amplification, inversions and translocations [65-67]. Pleural mesotheliomas show considerable genetic variability between morphologic subtypes or patients $[58,59,68-70]$, suggesting that a single targeted therapy is unlikely to be beneficial for all patients. Figure 2 lists commonly affected genes in pleural mesothelioma grouped by canonical pathways [58, 59, 68-70]. Such classification is useful to help identify altered cellular mechanisms amenable to therapeutic intervention. Some of the commonly identified mutated or deleted genes in

\section{(A) Incidence Sites}

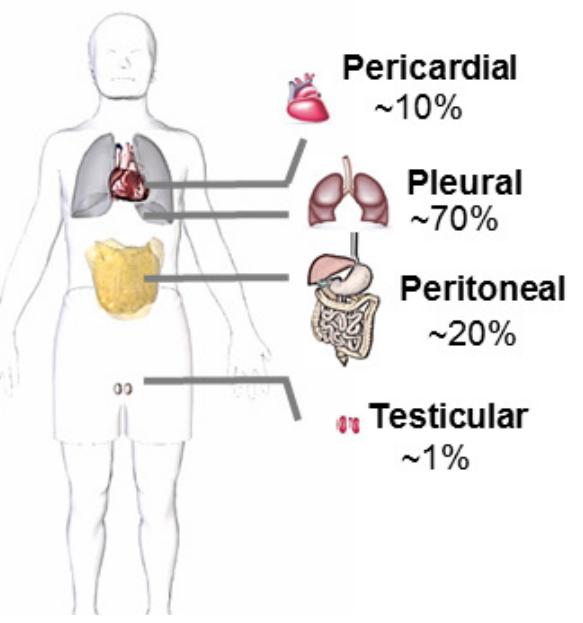

(B) Pathology Subtypes

Epithelioid
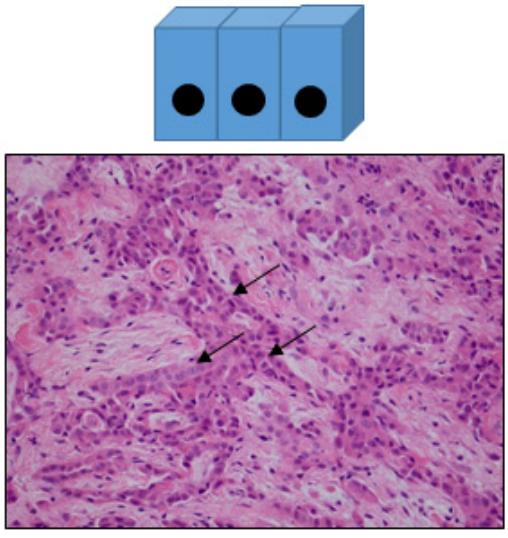

\section{Sarcomatoid}
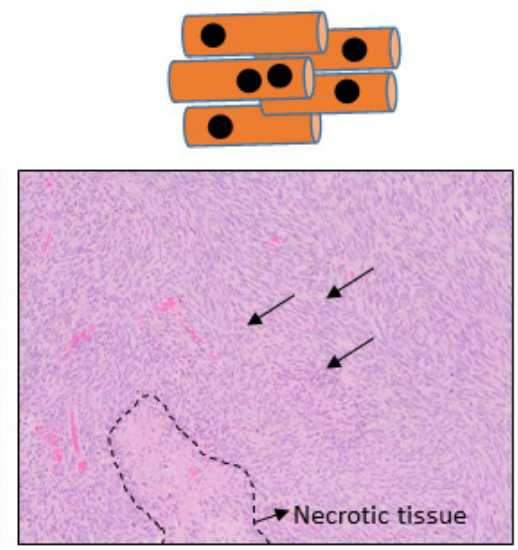

Figure 1: Common sites of incidence and pathological subtypes of pleural mesothelioma. (A) Tissues affected by mesothelioma and incidence rates. (B) Hematoxylin and eosin staining of two mesothelioma pathologic subtypes (epithelioid and sarcomatoid). Biphasic phenotype is a mixture of epithelioid and sarcomatoid types. The arrows indicate disorganized neoplastic tumor areas. 
pleural mesotheliomas such as BAP1 [67], NF2 [71], LATS1, 2 [63, 72-74], PBRM1 [67], TP53 [75-77], AURKA [78], CDKN2A [79], RB1 [80], BRCA2 [81], CCND1 [82], SETD2 [83], SMARCC1 [67] or PCNA [84] are also found in other cancer types. Knowledge of these commonly aberrant genes from other cancer types should be employed in mesothelioma research to help advance precision targeted therapy.

In addition to the cancer cell intrinsic mediators of tumor progression listed above, the tumor microenvironment is known to regulate a variety of genes associated with tumor progression, treatment resistance, and an aggressively metastatic tumor phenotype. The potential role of the tumor microenvironment and tumor hypoxia in driving mesothelioma progression has been under-studied despite evidence that mesotheliomas contain hypoxic tumor cells [85-87]. In this review, we discuss the potential influence of hypoxia on mesothelioma biology and argue that consideration of hypoxia in addition to secondarily affected genes and pathways may permit the design of more specific multi-modal drugs that are activated in hypoxic environments for selective killing of malignant cells [88], improving clinical outcome, and reducing morbidity due to mesothelioma.

\section{The hypoxic microenvironment of mesotheliomas: clinical and biological evidence}

Normal tissues exist over a range of oxygen tensions, and low levels of oxygen (hypoxia) are required for a variety of normal processes including embryogenesis, wound healing, and stem cell renewal in the bone marrow. In solid tumors, hypoxia (defined as $\mathrm{pO}_{2}<10 \mathrm{mmHg}$, equivalent to $<1.3 \% \mathrm{O}_{2}$ in vitro) is created when oxygen demand by the proliferating tumor cells exceeds the supply of oxygen provided to the tumor through the bloodstream $[63,89]$ (see Figure 3A). Tumor hypoxia is a significant barrier to effective treatment since hypoxic tumor cells are known to be resistant to radiation and most chemotherapy, while also promoting the enrichment of tumor cells with stem-like properties [90, 91]. Hypoxia is also associated with tumor progression and metastasis through the activity of the heterodimeric transcription factors hypoxiainducible factor-1 (HIF-1) and HIF-2's [92], $\alpha$ and $\beta$ subunits. In normoxic conditions, hydroxylated HIF-1 $\alpha$ is ubiquitinated by von-Hippel-Lindau E3 ubiquitin ligase and degraded by the proteasome. However, HIF prolylhydroxylases (using oxygen as a co-substrate), inhibited under hypoxic conditions, cannot hydroxylate HIF- $1 \alpha$

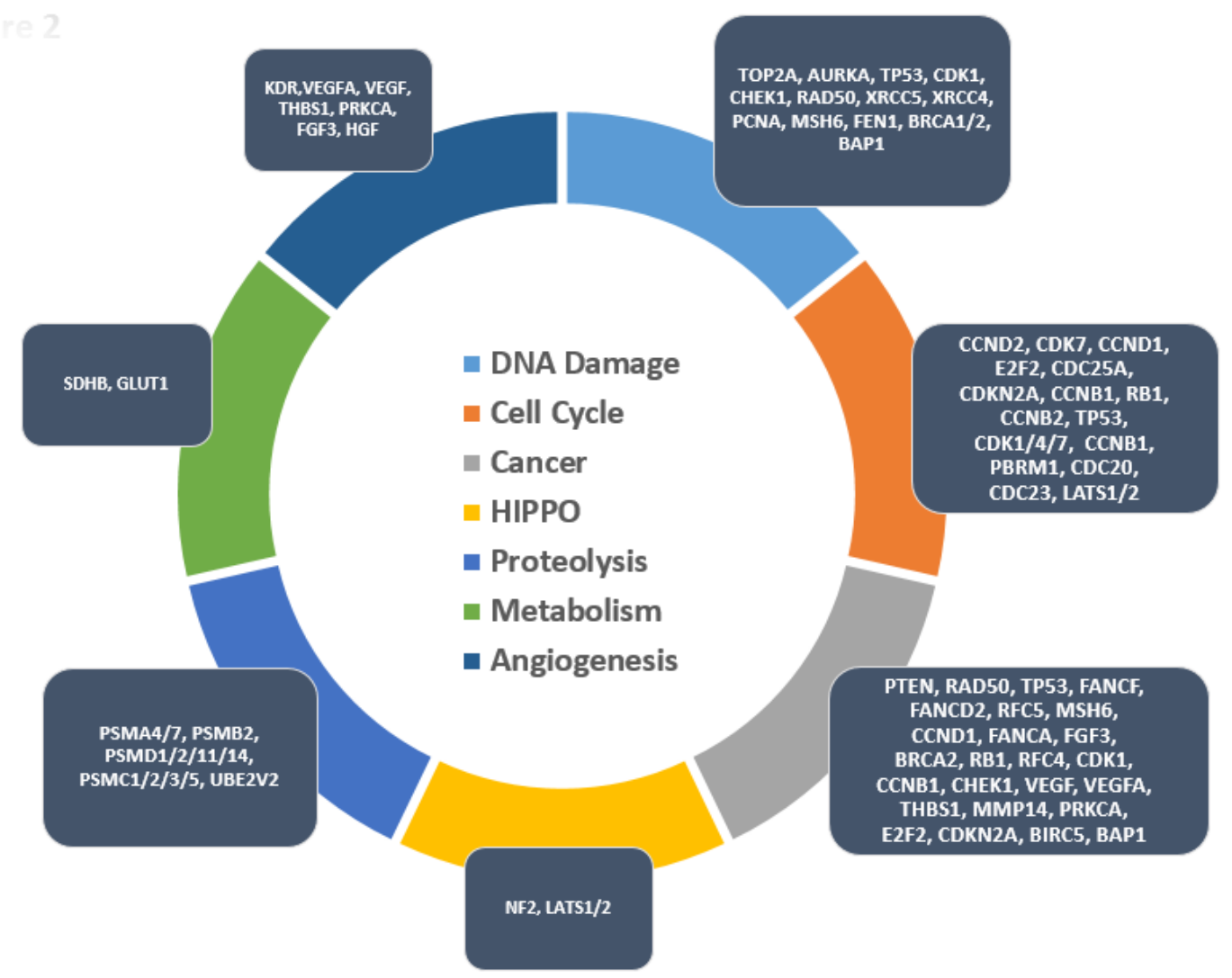

Figure 2: Compilation of common pleural mesothelioma genes and biological pathways: genetic aberrations in pleural mesothelioma and affected downstream signaling pathways, data source extraction from [58, 59, 68-70]. 
at its proline residues and thus stabilize HIF-1 $\alpha$ [93]. Consequently, HIF signaling cascade activation, due to changes in cellular oxygen concentration, mediates the expression of genes having HIF-responsive elements in their promoters [94]. These genes are implicated in switching and regulating massive pathways such as angiogenesis, metabolism, and survival [95]. Therefore, it is imperative to consider the co-selection of interconnected pathways and their associations with the development of aggressive malignancy.

Laparoscopy or pleuroscopy show that the healthy intraperitoneal or intrapleural cavities exhibit negative pressures lower than atmospheric pressure $[91,96]$. Physiological negative pressure in one study is associated with less than 4\% oxygen [97]. Furthermore, mesotheliomas are particularly hypoxic solid tumor masses $[85,92]$ as evidenced by binding of 2-nitroimidazole or pimonidazole as exogenous hypoxia markers $[98,99]$ and elevated levels of HIF- $1 \alpha[100,101]$ as endogenous hypoxia marker. Imaging evidence from [F-18] fluoromisonidazole (FMISO) PET-CT scanning confirms hypoxia being integral to mesotheliomas [97].

Cancer cells derive their energy from aerobic glycolytic metabolism for cellular processes based on Warburg's classical observations [102]. Hypoxia, however, triggers a metabolic reprograming of cancers [91] to increase glucose uptake and the flux from pyruvate to lactate. This phenomenon is clinically assessed in mesotheliomas through PET/CT imaging with $2-\left[{ }^{19} \mathrm{~F}\right]-$ fluoro-2-deoxy-D-glucose (F-FDG) tracers [89]. In vivo, F-FDG uptake in pleural mesotheliomas shows high correlations with GLUT1, HIF1, VEGF, CD34, Ki67, and MTOR upregulation [93], and poor patient prognoses. Interestingly, $H I F-1$ activation increases glucose transport (via GLUT-1) as well as glutamine and L-type amino acid transport (via LAT1) in pleural mesotheliomas [91, 95]. Hypoxia facilitates this switch from oxidative phosphorylation to anaerobic glycolysis [103].

In Figure 3B, we summarize hypoxia-related changes in pathways inherent to solid tumors and commonly aberrant genes found in mesotheliomas. Understanding how mesotheliomas respond to hypoxia and whether selective hypoxia-responsive prodrugs delivered to such tissues are more therapeutically effective remain largely under-investigated and unsolved questions in the mesothelioma field.

\section{Hypoxia-targeting drugs and strategies for malignant mesotheliomas}

Hypoxia as a unique feature of solid tumor biology provokes a need for clinically applicable gene expression signatures and poses a great opportunity for selective antitumor therapies [23, 34]. Apart from the promising direct targeting of HIF-1 $\alpha$ in tumors, other potential avenues for therapeutic exploration are prodrugs and enzymes for treatment of cells or tumors under hypoxia. These are listed in table 1, adapted from [1, 104-106].

Therapeutically, hypoxia is exploited in cancer treatment by bioreductive prodrugs such as $\mathrm{AQ} 4 \mathrm{~N}$, PR-104, TH-302 or hypoxia-responsive polymeric nanoparticles (containing chemotherapy) [104-107]. These can be likened to 'Trojan horses', i.e. normally inactive drug derivatives that undergo bioactivation via enzymatic or chemical transformations [85, 88, 107] under hypoxic conditions. Other strategies explored to date are hypoxia-responsive polymeric nanoparticles, magnetic nanoparticles, small molecule inhibitors, or hypoxia-triggered prodrug micelles that carry and selectively release therapeutic agents in the hypoxic microenvironment of the tumors. Several surrogate markers for recognizing tumor hypoxia are hypoxiarelated endogenous proteins (GLUT-1 and CA-IX due to presence of HIF-responsive elements in promoters) as well as exogenous bioreductive hypoxia drugs (Tirapazamine, PR-104, TH-302) [108-110].

Along with well-known GLUT-1 regulation, carbonic anhydrases (CA), large family of zinc metalloproteases, are strongly upregulated by HIF-1 and are required for maintenance of $\mathrm{pH}$, proliferation, and metastasis [111, 112]. CA-IX is a membrane associated isoform showing extensive diversity in tissue distributions and in subcellular localizations [71]. It is an established endogenous marker of hypoxia, and particularly overexpressed in VHL mutated clear cell renal cell carcinomas $[113,114]$, mesotheliomas [115, 116], kidney [15], as well as other hypoxic solid tumors [113]. CA-IX expression is correlated with poor patient prognosis, metastasis, and therapy resistance $[5,71$, 117]. This is particularly interesting as more than $90 \%$ of mesotheliomas are positive for CA-IX [95, 115, 118] and so one would expect its inhibition would limit $\mathrm{pH}-$ driven growth and metastasis. Monoclonal antibodies and small molecule inhibitors specific to CA-IX are being investigated for potential targeted therapeutics in the pre-clinical studies. Regardless, the sequence of administration in combination with other chemotherapies in mesotheliomas warrants careful investigation. Further, the modest improvements in disease-free survival following hypoxia-targeted therapies in over 30 clinical trials $[119,120]$ demonstrates the need for considering tumor heterogeneity, hypoxia assessment, and patient stratification prior to therapy.

\section{Hypoxia-induced angiogenesis and mesothelioma pathogenesis}

The vasculature delivers oxygen and nutrients to all cells within the body. Hypoxic regions trigger HIFrelated pathways that are key regulators of sprouting 
angiogenesis via modulating vascular endothelial growth factor (VEGF) [121]. VEGF-induced pro-survival pathways in solid tumors is a pivotal and early event in the development of metastatic malignancies [122]. Strikingly, VEGF along with multiple RTKs essential for VEGF-mediated angiogenesis, including epidermal growth factor receptor (EGFR), MET, and AXL, are activated in pleural mesothelioma cell lines and tumors [123-126]. Although clinical trial results for EGFR inhibitors in mesothelioma have not been released, concurrent inhibition of various activated RTKs with proapoptotic and anti-proliferative effects in mesothelioma cell lines have paved the way to such trials [127]. It is noteworthy that hypoxia induces the activity of tyrosine kinase inhibitors [128]. This selective activation under hypoxia would beis therefore an interesting avenue to explore [129] compared to conventional cytotoxic drugs that affect all cells. There are numerous studies using antiangiogenic agents Bevacizumab and Sunitinib (VEGF inhibitors), and Sorafenib (tyrosine kinase inhibitor) for cancer therapy with beneficial results for patients with other tumor types $[101,130]$. A randomized phase II trial has not significantly improved progression-free survival in pleural mesothelioma patients [131], arguably for the same reason that patients aren't stratified based on tumor hypoxia assessments [132]. Anti-VEGF inhibitors do elicit response in primary tumors but evasive resistance develops and results in aggressive regression in glioblastomas [99, 133]. Antiangiogenic effects of agents such as Bevacizumab in combination with hypoxia-activated prodrugs or HIF-1 inhibitors and standard chemotherapies, however, have served as attractive strategies to target the hypoxic tumor microenvironment in triple negative breast cancer and gliomas [115, 134, 135]. VEGF inhibitor
(NCT00651456) in addition to chemotherapy in pleural mesothelioma patients is currently in phase III clinical trials with longer survival success [J Clin Oncol 33, 2015 (abstract 7500)]. A consideration of sequential multimodal regimens of therapy is arguably the reason behind lack of improvements in patient survival rate. A sequential multi-modal regimen of chemotherapy, VEGF and HIF inhibitors in addition to other secondary hypoxia-activated pathways would require thorough preclinical and clinical investigations.

\section{Hypoxia-induced proliferation inMesotheliomas}

$\mathrm{PI} 3 \mathrm{~K} / \mathrm{AKT} / \mathrm{MTOR}$ is an oxygen and energy-sensing pathway essential for regulation of cell cycle progression and cell proliferation [136], and closely associated with hypoxic signaling (e.g. mediating HIF-1 regulation) [137, 138]. Epithelioid-type pleural mesothelioma cells show activation of PI3K/AKT/MTOR signaling [139141]. PI3K/AKT/MTOR signaling is partly dependent upon coordinated activation of multiple receptor tyrosine kinases (RTKs), such as EGFR, MET or AXL [127, 140]. Interestingly, signaling through these RTKs has also been found to be altered in 8 out of 9 pleural mesothelioma cell lines and 6 of 12 mesothelioma biopsies [136]. There are currently phase I, II, and III clinical trials evaluating AXL inhibitor (BGB324) in colon cancer [142], MET inhibitor (INC280) in papillary renal cell cancer, and EGFR inhibitor (NCT02206763) in non-small cell lung cancer and so re-purposing the successful ones for mesothelioma therapy will be essential. Further, although a direct link between PI3K/AKT/MTOR and hypoxia has not been established in mesothelioma, an integrated multi-modal
(A)
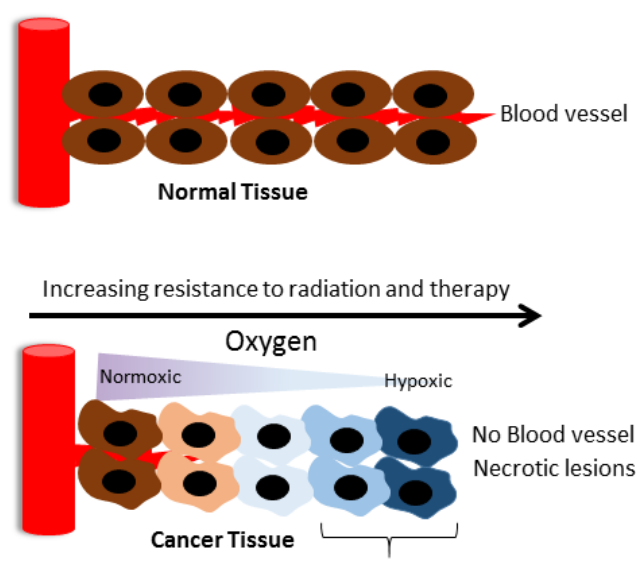

$\mathrm{pO} 2<10 \mathrm{mmHg}$ Or $<1.3 \% \mathrm{O} 2$ in vitro
(B)

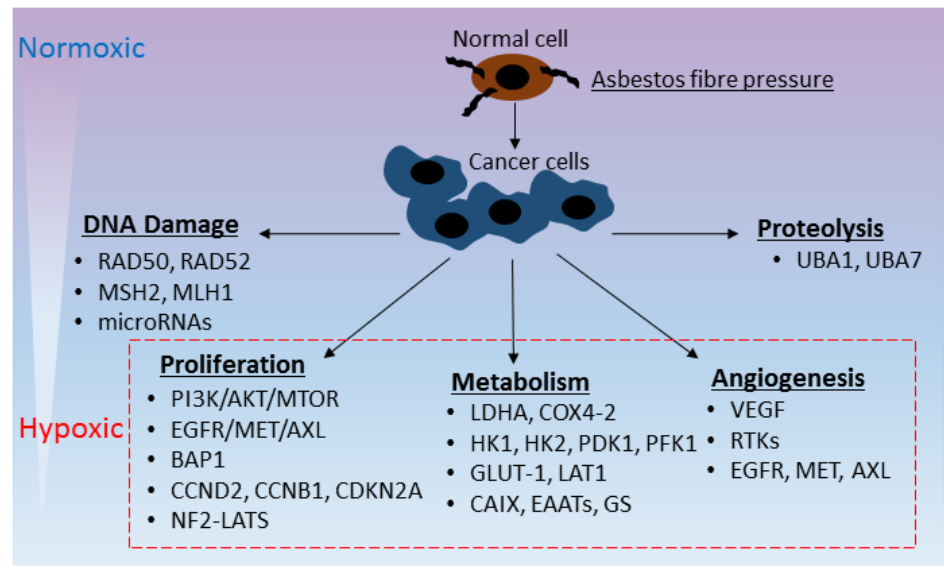

Figure 3: Tumor hypoxia, therapy resistance, and alterations in downstream pathways. (A) Tumor hypoxia model of pleural mesothelioma: hypoxia arising in solid tumor tissue regions most distant from the vasculature. (B) Hypoxic cancer cells switch on target genes involved in cell proliferation, DNA damage, metabolism, proteolysis, and angiogenesis pathways leading to cancer cell survival and metastasis. Indicated genes in each pathway are specific to mesotheliomas but also found in other cancers. 
Table 1: Bioreductive prodrugs or polymeric nanoparticles targeting tumor hypoxia

\author{
Hypoxia-activated cytotoxins \\ Nitro- cyclic compounds \\ Aromatic $\mathrm{N}$-oxidases \\ Aliphatic N-oxidases \\ Quinones \\ Metal complexes \\ Polymeric nanoparticles
}

\author{
Hypoxia Inhibition \\ HIF1 inhibitors
}

approach to target pathways affecting cell proliferation and survival under hypoxia remain to be investigated (Table 2).

A tumor suppressor gene most commonly deleted or mutated in mesotheliomas ( $60 \%$ of cases) is $B R C A 1$ associated protein-1 (BAP1), a C-terminal family of deubiquitinating enzymes (DUBs) linked to DNA damage repair regulation [36, 63, 67, 83, 143-145]. $B A P 1$ 's function has been implicated in various other cancer types such as uveal melanoma [113], clear cell renal cell carcinoma [114], and cutaneous melanocytic tumors $[113,116]$. Although BAPl's crystal structure has been solved [92], a therapeutic drug for patients carrying mutations of BAP1 has not been developed. Moreover, cell cycle related genes often found mutated in pleural mesothelioma and regulated by hypoxic stress [132, 135] are cyclin-dependent kinases (such as $\sim 15-45 \%$ incidence in deletions of $C D K N 1,2 A)$ [22, 83, 146, 147]. Using drugs that target these genes in combination with hypoxia-specific cytotoxins warrants pre- and clinical investigations. Of note are CDK4 inhibitor (palbociclib) trials for non-mesothelioma cancer patients under way that could be repurposed for mesotheliomas. Interestingly, BAP1 inactivation is associated with carbonic anhydrase 9 (CA-IX) expression [15].

Additionally, two important genes consistently found mutated or inactivated in pleural mesotheliomas are neurofibromin or merlin (NF2, with $\sim 45 \%$ incidence of aberration), a negative regulator of E3 ubiquitin ligase, and the Large Tumor Suppressor kinase 1/2 (LATS1/2, with $\sim 30 \%$ incidence of aberration), two components of the Hippo pathway [22, 83, 148]. Both NF2 and LATS2 can be regulated by hypoxia [149] but this particular link has not been studied in mesothelioma. The co-targeting of both LATS2 and NF2 delivered into the hypoxic tumors may prove more potent and call for thorough clinical investigations (table 2).

\author{
Examples \\ PR-104, TH-302 \\ TPZ, SR4233 \\ AQ4N \\ Porfiromycin, RH1, EO9 \\ Cobalt/nitrogen/copper complexes \\ HR-NPs \\ Examples \\ Topotecan, YC-1, PX-478
}

\section{Hypoxia-induced DNA damage repair in mesotheliomas}

Typically, as an adaptive response to hypoxia, tumors increase genetic instability by down regulating DNA repair genes such as MLH1, MSH2, RAD50-2 and activating ATM and ATR DNA damage checkpoint pathways $[121,150,151]$. The homologous and nonhomologous recombination as well as mismatch are inhibited under hypoxia, increasing unrepaired replication errors and double stranded breaks [117]. More specifically, cells under hypoxia and/or reoxygenation are most sensitive to loss or inhibition of CHEK1, ATM, and ATR [152]. In pleural mesotheliomas, tumor suppressor genes MSH6 (heterodimer partner of MSH2) and RAD50 are highly overexpressed, especially post-chemotherapy [30]. Further, CHEK1, required for checkpoint mediated cell cycle arrest in response to DNA damage, is overexpressed [30] in pleural mesotheliomas. A CHEK1 inhibitor, LY2606369, is currently used in clinical trials for breast cancer patients with BRCA1/2 mutations and could be re-purposed for treating pleural mesothelioma malignancy. Other DNA damage repair genes deregulated in mesotheliomas include Fanconi anemia group D2 (FANCD2), RAD21 and RAN [153]. Thus, co-targeting DNA damage genes in addition to chemotherapy may improve patient survival.

$R A D 52$, another key gene involved in homologous recombination repair, is important for chemotherapy resistance and can be translationally repressed by miR- 210 [150], a microRNA regulated by hypoxia. Additionally, there are many microRNAs identified to date to be associated with poor survival in mesotheliomas (miR210, mir-126, miR-125a-5p, miR-484, miR-320, and let7a, miR-29c, miR-16, miR-31, miR-34 [154-156], miR141, miR-200a, miR-200b, miR-200c, miR-203, miR-205, and miR-429 [157], and miR-193, miR-200, and miR-192 $[158,159]$ with diagnostic confidence). Remarkably, 


\begin{tabular}{|c|c|c|c|}
\hline Clinical Trial ID & Phase & Agent Tested & Mechanisms of Action \\
\hline NCT01675765 & I & CRS-207 & Immunotherapy Against Tumor Associated Antigen Mesothelin \\
\hline NCT01870609 & II & VS-6063 & Tumor NF2 Antagonist \\
\hline NCT02071862 & I & CB-839 & Glutaminase Inhibitor \\
\hline NCT00685204 & II & TL139 & Taxane \\
\hline NCT02372227 & I & VS-6063 & Dual PI3K/mTOR Inhibitor \\
\hline NCT01655225 & I & LY3023414 & Inhibit CYP3A4-mediated Metabolism \\
\hline NCT01997190 & I & AdV-tk & Adenovirus-mediated Herpes Simplex Virus Against Thymidine Kinase \\
\hline NCT00996567 & II & Cetuximab & Antibody Against EGFR \\
\hline NCT01938443 & I & GSK2256098 & FAK Inhibitor \\
\hline NCT01358084 & II & NGR-hTNF & Vascular Targeting Agent \\
\hline NCT01211275 & II & Axitinib & VEGF Angiogenesis Inhibitor \\
\hline
\end{tabular}

hypoxic cells also show lower expression levels of miR141 [86]. The therapeutic potential of using microRNA mimics $[160,161]$ in conjunction with hypoxiaresponsive polymeric nanoparticles in vivo demands closer investigations and gives countless potentially druggable targets for the development of innovative cures.

\section{Hypoxia-induced proteolysis in mesotheliomas}

Under cellular stress conditions (e.g. low nutrient or oxygen levels), alteration/induction of proteasome and autophagic lysosome degradation pathways occurs as an adaptive response to mitigate the new cellular energy demands $[162,163]$. Specifically, severe hypoxia increases unfolded protein response (UPR), causes accumulation of unfolded proteins in the endoplasmic reticulum (ER), and leads to more stress [88, 164]. Further, UPR can subsequently activate autophagy to alleviate stress via inducing apoptosis, increasing cell survival and proliferation [165]. Interestingly, the ubiquitin-proteasome pathway is differentially regulated in epithelioid versus biphasic pleural mesotheliomas [166]. Epithelioid pleural tumors have lower levels of ubiquitin specific proteases and higher levels of ubiquitin-activating enzyme E1, which associates with long term survival [167]. Shortterm survivors have higher proteasome subunits [168]. Higher levels of Cullin 4A, an ubiquitin ligase E3, are reported in pleural mesotheliomas [169]. The selective ER stress-inducing agents and UPR inhibitors can be particularly promising in mesothelioma targeted therapy. For instance, inhibiting the UPR (with MG132 and PSI) results in apoptosis and inhibition of invasion in malignant pleural mesothelioma cells $[170,171]$. Proteasome inhibitor, Bortezomib is currently in phase II clinical trials in combination with chemotherapy showing improved patient outcome for pleural mesothelioma [172]. Intriguingly, the link between hypoxia and proteolysis has not been thoroughly investigated in mesotheliomas.

\section{CONCLUDING REMARKS}

Some of the outstanding questions in the field of malignant mesothelioma biology include deciphering which molecular events are involved in the genesis of mesotheliomas and would this inter and intra-heterogeneity among tumors change from onset to progression? Understanding the genomic landscape of mesotheliomas and integrating that knowledge for designing optimal and tailored therapeutic strategies is critical for improved patient outcome. Another important aspect is to understand whether and how the microenvironment of malignant mesotheliomas contributes to changes in oxygen permeability, nutrition and $\mathrm{pH}$ of tumors [173] and whether sustained $H I F$ induction is necessary for continued growth and survival of these tumors.

Hypoxic cells within the tumor mass are distant from blood vessels, resistant to most anticancer drugs, and present a major obstacle to delivery of targeted therapies. In this review, we suggest that the hypoxic environment of solid tumor mesotheliomas can be used as the Achilles' heel for targeted drug delivery. We ask whether new therapies for pleural mesothelioma, such as those being used in clinical trials worldwide (Table 2), prove more effective if tumor-hypoxia is carefully assessed and therapies are administered in combination with hypoxiabased therapies.

How we address the challenge of individualized and direct assessment of oxygen pressure within mesotheliomas, correlate that measurement to tumor function, and incorporate it as part of a standard of care remain outstanding areas for investigations. 


\section{ACKNOWLEDGEMENTS}

We would like to give special thanks to Mark Weintraub, Q.C. and family who have been instrumental in forming a Vancouver-based mesothelioma research group in memory of Danyael Elise Weintraub. Thanks to Drs. Brandon Sheffield and Peter Gout for the critical reading of this manuscript. We would also like to thank Susan Ettinger, Shawn Anderson, and Robert Bell for their reading of this manuscript. A more comprehensive and current list of mesothelioma clinical trials can be found at: https://www.centerwatch.com/clinical-trials/listings/ condition/192/mesothelioma.

\section{FINANCIAL SUPPORT}

This work was supported by the Canadian Institutes of Health Research (K.L.B., Y.W.), BC Cancer Foundation Mesothelioma Research Fund/Mitacs Accelerate Postdoctoral Fellowship Fund (N.N., Y.W., C.C.C.), and the Terry Fox New Frontiers Program on Prostate Cancer Progression (C.C.C., Y.W.). K.L.B is a Michael Smith Foundation for Health Research Biomedical Research Scholar.

\section{CONFLICTS OF INTEREST}

The authors confirm that there are no conflicts of interest.

\section{REFERENCES}

1. Carbone M, Klein G, Gruber J, Wong M. Modern Criteria to Establish Human Cancer Etiology. Cancer Research. 2004;64(15):5518-24.

2. Law MR, Hodson ME, Heard BE. Malignant mesothelioma of the pleura: relation between histological type and clinical behaviour. Thorax. 1982;37(11):810-5.

3. Rudd RM. Malignant mesothelioma. British Medical Bulletin. 2010;93(1):105-23.

4. Gerbaudo VH, Katz SI, Nowak AK, Francis RJ. Multimodality Imaging Review of Malignant Pleural Mesothelioma Diagnosis and Staging. PET Clinics. 2011;6(3):275-97.

5. Godar M, Liu J, Zhang P, Xia Y, Yuan Q. Primary Pericardial Mesothelioma: A Rare Entity. Case Reports in Oncological Medicine. 2013;2013:283601.

6. Meyerhoff RR, Yang C-FJ, Speicher PJ, Gulack BC, Hartwig MG, D'Amico TA, Harpole DH, Berry MF. Impact of mesothelioma histologic subtype on outcomes in the Surveillance, Epidemiology, and End Results database. The Journal of surgical research. 2015;196(1):23-32.

7. Soeberg MJ, Leigh J, Driscoll T, Armstrong B, Young JM, van Zandwijk N. Incidence and survival trends for malignant pleural and peritoneal mesothelioma, Australia, 1982-2009. Occupational and Environmental Medicine. 2016;73(3):187-94.

8. Price B, Ware A. Time trend of mesothelioma incidence in the United States and projection of future cases: An update based on SEER data for 1973 through 2005. Critical Reviews in Toxicology. 2009;39(7):576-88.

9. Weill H, Hughes J, Churg A. Changing trends in US mesothelioma incidence. Occupational and Environmental Medicine. 2004;61(5):438-41.

10. Bianchi C, Bianchi T. Global mesothelioma epidemic: Trend and features. Indian Journal of Occupational and Environmental Medicine. 2014;18(2):82-8.

11. Henley SJ, Larson TC, Wu M, Antao VC, Lewis M, Pinheiro GA, Eheman C. Mesothelioma incidence in 50 states and the District of Columbia, United States, 2003-2008. International journal of occupational and environmental health. 2013;19(1):1-10.

12. Robinson BM. Malignant pleural mesothelioma: an epidemiological perspective. Annals of Cardiothoracic Surgery. 2012;1(4):491-6.

13. Muers MF, Stephens RJ, Fisher P, Darlison L, Higgs CMB, Lowry E, Nicholson AG, O'Brien M, Peake M, Rudd R, Snee M, Steele J, Girling DJ, et al. Active symptom control with or without chemotherapy in the treatment of patients with malignant pleural mesothelioma (MS01): a multicentre randomised trial. Lancet. 2008;371(9625):1685-94.

14. Nowak AK. Chemotherapy for malignant pleural mesothelioma: a review of current management and a look to the future. Annals of Cardiothoracic Surgery. 2012;1(4):508-15.

15. Wang S-S, Gu Y-F, Wolff N, Stefanius K, Christie A, Dey A, Hammer RE, Xie X-J, Rakheja D, Pedrosa I, Carroll T, McKay RM, Kapur P, et al. Bap1 is essential for kidney function and cooperates with Vhl in renal tumorigenesis. Proceedings of the National Academy of Sciences of the United States of America. 2014;111(46):16538-43.

16. Mott FE. Mesothelioma: A Review. The Ochsner Journal. 2012;12(1):70-9.

17. Opitz I. Management of malignant pleural mesotheliomaThe European experience. Journal of Thoracic Disease. 2014;6(Suppl 2):S238-S52.

18. Papaspyros S, Papaspyros S. Surgical management of malignant pleural mesothelioma: impact of surgery on survival and quality of life-relation to chemotherapy, radiotherapy, and alternative therapies. ISRN surgery. 2014;2014:817203.

19. Zhang W, Wu X, Wu L, Zhang W, Zhao X. Advances in the diagnosis, treatment and prognosis of malignant pleural mesothelioma. Annals of Translational Medicine. 2015;3(13).

20. Sugarbaker PH, Welch LS, Mohamed F, Glehen O. A review of peritoneal mesothelioma at the Washington Cancer Institute. Surgical oncology clinics of North America. 
2003;12(3):605-21, xi.

21. Fennell DA, Gaudino G, O'Byrne KJ, Mutti L, van Meerbeeck J. Advances in the systemic therapy of malignant pleural mesothelioma. Nat Clin Prac Oncol. 2008;5(3):136-47.

22. Stahel RA, Weder W, Felley-Bosco E, Petrausch U, CurioniFontecedro A, Schmitt-Opitz I, Peters S. Searching for targets for the systemic therapy of mesothelioma. Annals of Oncology. 2015.

23. Baumann F, Ambrosi J-P, Carbone M. Asbestos is not just asbestos: an unrecognised health hazard. The Lancet Oncology. 2013;14(7):576-8.

24. Huncharek M. Non-asbestos related diffuse malignant mesothelioma. Tumori. 2002;88(1):1-9.

25. Carbone M, Baris YI, Bertino P, Brass B, Comertpay S, Dogan AU, Gaudino G, Jube S, Kanodia S, Partridge CR, Pass HI, Rivera ZS, Steele I, et al. Erionite exposure in North Dakota and Turkish villages with mesothelioma. Proc Natl Acad Sci U S A. 2011;108(33):13618-23.

26. Nishimura Y, Kumagai-Takei N, Matsuzaki H, Lee S, Maeda M, Kishimoto T, Fukuoka K, Nakano T, Otsuki T. Functional Alteration of Natural Killer Cells and Cytotoxic T Lymphocytes upon Asbestos Exposure and in Malignant Mesothelioma Patients. BioMed Research International. 2015;2015:238431.

27. Carbone M, Yang H. Molecular pathways: targeting mechanisms of asbestos and erionite carcinogenesis in mesothelioma. Clinical cancer research : an official journal of the American Association for Cancer Research. 2012;18(3):598-604.

28. Jube S, Rivera ZS, Bianchi ME, Powers A, Wang E, Pagano I, Pass HI, Gaudino G, Carbone M, Yang H. Cancer cell secretion of the DAMP protein HMGB1 supports progression in malignant mesothelioma. Cancer Res. 2012;72(13):3290-301.

29. Branchaud RM, MacDonald JL, Kane AB. Induction of angiogenesis by intraperitoneal injection of asbestos fibers. FASEB journal : official publication of the Federation of American Societies for Experimental Biology. 1989;3(6):1747-52.

30. Roe OD, Anderssen E, Sandeck H, Christensen T, Larsson E, Lundgren S. Malignant pleural mesothelioma: genomewide expression patterns reflecting general resistance mechanisms and a proposal of novel targets. Lung cancer (Amsterdam, Netherlands). 2010;67(1):57-68.

31. Benedetti S, Nuvoli B, Catalani S, Galati R. Reactive oxygen species a double-edged sword for mesothelioma. Oncotarget. 2015;6(19):16848-65.

32. Heintz NH, Janssen-Heininger YM, Mossman BT. Asbestos, lung cancers, and mesotheliomas: from molecular approaches to targeting tumor survival pathways. American journal of respiratory cell and molecular biology. 2010;42(2):133-9.

33. Kaiglova A, Kovacikova Z, Hurbankova M. Impact of acute and subchronic asbestos exposure on some parameters of antioxidant defense system and lung tissue injury. Industrial health. 1999;37(3):348-51.

34. Carbone M, Flores EG, Emi M, Johnson TA, Tsunoda T, Behner D, Hoffman H, Hesdorffer M, Nasu M, Napolitano A, Powers A, Minaai M, Baumann F, et al. Combined Genetic and Genealogic Studies Uncover a Large BAP1 Cancer Syndrome Kindred Tracing Back Nine Generations to a Common Ancestor from the 1700s. PLoS Genet. 2015;11(12):e1005633.

35. Napolitano A, Pellegrini L, Dey A, Larson D, Tanji M, Flores EG, Kendrick B, Lapid D, Powers A, Kanodia S, Pastorino S, Pass HI, Dixit V, et al. Minimal asbestos exposure in germline BAP1 heterozygous mice is associated with deregulated inflammatory response and increased risk of mesothelioma. Oncogene. 2015.

36. Testa JR, Cheung M, Pei J, Below JE, Tan Y, Sementino E, Cox NJ, Dogan AU, Pass HI, Trusa S, Hesdorffer M, Nasu M, Powers A, et al. Germline BAP1 mutations predispose to malignant mesothelioma. Nat Genet. 2011;43(10):1022-5.

37. Izzi V, Masuelli L, Tresoldi I, Foti C, Modesti A, Bei R. Immunity and malignant mesothelioma: from mesothelial cell damage to tumor development and immune responsebased therapies. Cancer letters. 2012;322(1):18-34.

38. Linton A, van Zandwijk N, Reid G, Clarke S, Cao C, Kao $\mathrm{S}$. Inflammation in malignant mesothelioma - friend or foe? Annals of Cardiothoracic Surgery. 2012;1(4):516-22.

39. Pinato DJ, Mauri FA, Ramakrishnan R, Wahab L, Lloyd T, Sharma R. Inflammation-Based Prognostic Indices in Malignant Pleural Mesothelioma. Journal of Thoracic Oncology. 2012;7(3):587-94.

40. Antman KH, Corson JM, Li FP, Greenberger J, Sytkowski A, Henson DE, Weinstein L. Malignant mesothelioma following radiation exposure. Journal of clinical oncology : official journal of the American Society of Clinical Oncology. 1983;1(11):695-700.

41. Goodman JE, Nascarella MA, Valberg PA. Ionizing radiation: a risk factor for mesothelioma. Cancer causes \& control : CCC. 2009;20(8):1237-54.

42. Qi F, Carbone M, Yang H, Gaudino G. Simian virus 40 transformation, malignant mesothelioma and brain tumors. Expert review of respiratory medicine. 2011;5(5):683-97.

43. Bocchetta M, Di Resta I, Powers A, Fresco R, Tosolini A, Testa JR, Pass HI, Rizzo P, Carbone M. Human mesothelial cells are unusually susceptible to simian virus 40-mediated transformation and asbestos cocarcinogenicity. Proc Natl Acad Sci U S A. 2000;97(18):10214-9.

44. Cacciotti P, Libener R, Betta P, Martini F, Porta C, Procopio A, Strizzi L, Penengo L, Tognon M, Mutti L, Gaudino G. SV40 replication in human mesothelial cells induces HGF/Met receptor activation: a model for viral-related carcinogenesis of human malignant mesothelioma. Proc Natl Acad Sci U S A. 2001;98(21):12032-7.

45. Carbone M. Simian virus 40 and human tumors: It is time 
to study mechanisms. Journal of Cellular Biochemistry. 2000;76(2):189-93.

46. Carbone M, Bocchetta M, Cristaudo A, Emri S, Gazdar A, Jasani B, Lednicky J, Miele L, Mutti L, Pass HI, Ramael M, Rizzo P, Testa JR, et al. SV40 and human brain tumors. International Journal of Cancer. 2003;106(1):140-2.

47. De Bruin ML, Burgers JA, Baas P, van 't Veer MB, Noordijk EM, Louwman MWJ, Zijlstra JM, van den Berg H, Aleman BMP, van Leeuwen FE. Malignant mesothelioma after radiation treatment for Hodgkin lymphoma. Blood. 2009;113(16):3679-81.

48. Weissmann LB, Corson JM, Neugut AI, Antman KH. Malignant mesothelioma following treatment for Hodgkin's disease. Journal of Clinical Oncology. 1996;14(7):2098100.

49. Shannon VR, Nesbitt JC, Libshitz HI. Malignant pleural mesothelioma after radiation therapy for breast cancer. A report of two additional patients. Cancer. 1995;76(3):43741.

50. Travis LB, Fosså SD, Schonfeld SJ, McMaster ML, Lynch CF, Storm H, Hall P, Holowaty E, Andersen A, Pukkala E, Andersson M, Kaijser M, Gospodarowicz M, et al. Second Cancers Among 40576 Testicular Cancer Patients: Focus on Long-term Survivors. Journal of the National Cancer Institute. 2005;97(18):1354-65.

51. Henderson DW, Reid G, Kao SC, van Zandwijk N, Klebe S. Challenges and controversies in the diagnosis of malignant mesothelioma: Part 2. Malignant mesothelioma subtypes, pleural synovial sarcoma, molecular and prognostic aspects of mesothelioma, BAP1, aquaporin-1 and microRNA. Journal of clinical pathology. 2013;66(10):854-61.

52. Smith M, Colby T. The diagnosis of thoracic malignant mesothelioma: practical considerations and recent developments. Turk patoloji dergisi. 2014;30(1):1-10.

53. Wagner D, Bourne PA, Yang Q, Goldman BI, Lewis JSJ, Xu H. Unusual Features of Malignant Pleural Mesothelioma Metastatic to the Mediastinal Lymph Nodes. Applied Immunohistochemistry \& Molecular Morphology. 2008;16(3):301-7.

54. Klebe S, Brownlee NA, Mahar A, Burchette JL, Sporn TA, Vollmer RT, Roggli VL. Sarcomatoid mesothelioma: a clinical-pathologic correlation of 326 cases. Mod Pathol. 2010;23(3):470-9.

55. van Zandwijk N, Clarke C, Henderson D, Musk AW, Fong K, Nowak A, Loneragan R, McCaughan B, Boyer M, Feigen M, Currow D, Schofield P, Nick Pavlakis BI, et al. Guidelines for the diagnosis and treatment of malignant pleural mesothelioma. Journal of Thoracic Disease. 2013;5(6):E254-E307.

56. Alexandrov LB, Nik-Zainal S, Wedge DC, Aparicio SA, Behjati S, Biankin AV, Bignell GR, Bolli N, Borg A, Borresen-Dale AL, Boyault S, Burkhardt B, Butler AP, et al. Signatures of mutational processes in human cancer. Nature. 2013;500(7463):415-21.
57. Røe OD, Anderssen E, Helge E, Pettersen CH, Olsen KS, Sandeck H, Haaverstad R, Lundgren S, Larsson E. Genome-Wide Profile of Pleural Mesothelioma versus Parietal and Visceral Pleura: The Emerging Gene Portrait of the Mesothelioma Phenotype. PLoS ONE. 2009;4(8):e6554.

58. Alakus H, Yost S, Woo B, French R, Lin G, Jepsen K, Frazer $\mathrm{K}$, Lowy A, Harismendy O. BAP1 mutation is a frequent somatic event in peritoneal malignant mesothelioma. Journal of Translational Medicine. 2015;13(1):122.

59. Sheffield BS, Tinker AV, Shen Y, Hwang H, Li-Chang HH, Pleasance E, Ch'ng C, Lum A, Lorette J, McConnell YJ, Sun S, Jones SJM, Gown AM, et al. Personalized Oncogenomics: Clinical Experience with Malignant Peritoneal Mesothelioma Using Whole Genome Sequencing. PLoS ONE. 2015;10(3):e0119689.

60. Guo G, Chmielecki J, Goparaju C, Heguy A, Dolgalev I, Carbone M, Seepo S, Meyerson M, Pass HI. WholeExome Sequencing Reveals Frequent Genetic Alterations in BAP1, NF2, CDKN2A, and CUL1 in Malignant Pleural Mesothelioma. Cancer Research. 2015;75(2):264-9.

61. Kettunen E, Nissén A-M, Ollikainen T, Taavitsainen M, Tapper J, Mattson K, Linnainmaa K, Knuutila S, El-Rifai We. Gene expression profiling of malignant mesothelioma cell lines: cDNA array study. International Journal of Cancer. 2001;91(4):492-6.

62. Pisick E, Salgia R. Molecular Biology of Malignant Mesothelioma: A Review. Hematology/Oncology Clinics of North America. 2005;19(6):997-1023.

63. Ladanyi M, Zauderer MG, Krug LM, Ito T, McMillan R, Bott M, Giancotti F. New Strategies in Pleural Mesothelioma: BAP1 and NF2 as Novel Targets for Therapeutic Development and Risk Assessment. Clinical cancer research : an official journal of the American Association for Cancer Research. 2012;18(17):4485-90.

64. Bueno R, De Rienzo A, Dong L, Gordon GJ, Hercus CF, Richards WG, Jensen RV, Anwar A, Maulik G, Chirieac LR, Ho K-F, Taillon BE, Turcotte CL, et al. Second Generation Sequencing of the Mesothelioma Tumor Genome. PLoS ONE. 2010;5(5):e10612.

65. Matullo G, Guarrera S, Betti M, Fiorito G, Ferrante D, Voglino F, Cadby G, Di Gaetano C, Rosa F, Russo A, Hirvonen A, Casalone E, Tunesi S, et al. Genetic Variants Associated with Increased Risk of Malignant Pleural Mesothelioma: A Genome-Wide Association Study. PLoS ONE. 2013;8(4):e61253.

66. Singhal S, Wiewrodt R, Malden LD, Amin KM, Matzie K, Friedberg J, Kucharczuk JC, Litzky LA, Johnson SW, Kaiser LR, Albelda SM. Gene Expression Profiling of Malignant Mesothelioma. Clinical Cancer Research. 2003;9(8):3080-97.

67. Yoshikawa Y, Emi M, Hashimoto-Tamaoki T, Ohmuraya M, Sato A, Tsujimura T, Hasegawa S, Nakano T, Nasu M, Pastorino S, Szymiczek A, Bononi A, Tanji M, et al. Highdensity array-CGH with targeted NGS unmask multiple 
noncontiguous minute deletions on chromosome 3 p21 in mesothelioma. Proceedings of the National Academy of Sciences. 2016;113(47):13432-7.

68. Crispi S, Calogero RA, Santini M, Mellone P, Vincenzi B, Citro G, Vicidomini G, Fasano S, Meccariello R, Cobellis G, Menegozzo S, Pierantoni R, Facciolo F, et al. Global Gene Expression Profiling Of Human Pleural Mesotheliomas: Identification of Matrix Metalloproteinase 14 (MMP-14) as Potential Tumour Target. PLoS ONE. 2009;4(9):e7016.

69. De Rienzo A, Archer MA, Yeap BY, Dao N, Sciaranghella D, Sideris AC, Zheng Y, Holman AG, Wang YE, Dal Cin P, Fletcher JA, Rubio R, Croft L, et al. Gender-Specific Molecular and Clinical Features underlie Malignant Pleural Mesothelioma. Cancer Research. 2015.

70. Sugarbaker DJ, Richards WG, Gordon GJ, Dong L, De Rienzo A, Maulik G, Glickman JN, Chirieac LR, Hartman M-L, Taillon BE, Du L, Bouffard P, Kingsmore $\mathrm{SF}$, et al. Transcriptome sequencing of malignant pleural mesothelioma tumors. Proceedings of the National Academy of Sciences. 2008;105(9):3521-6.

71. Borczuk AC, Pei J, Taub RN, Levy B, Nahum O, Chen J, Chen K, Testa JR. Genome-wide analysis of abdominal and pleural malignant mesothelioma with DNA arrays reveals both common and distinct regions of copy number alteration. Cancer Biology \& Therapy. 2016;17(3):328-35.

72. Carbone M, Ferris LK, Baumann F, Napolitano A, Lum CA, Flores EG, Gaudino G, Powers A, Bryant-Greenwood P, Krausz T, Hyjek E, Tate R, Friedberg J, et al. BAP1 cancer syndrome: malignant mesothelioma, uveal and cutaneous melanoma, and MBAITs. J Trans1 Med. 2012;10:179.

73. Hakiri S, Osada H, Ishiguro F, Murakami H, MurakamiTonami Y, Yokoi K, Sekido Y. Functional differences between wild-type and mutant-type BRCA1-associated protein 1 tumor suppressor against malignant mesothelioma cells. Cancer Science. 2015;106(8):990-9.

74. McMillan R, Zauderer M, Bott M, Ladanyi M. Important recent insights into the genetics and biology of malignant pleural mesothelioma. Annals of Cardiothoracic Surgery. 2012;1(4):462-5.

75. Olivier M, Hollstein M, Hainaut P. TP53 Mutations in Human Cancers: Origins, Consequences, and Clinical Use. Cold Spring Harbor Perspectives in Biology. 2010;2(1):a001008.

76. Andujar P, Pairon JC, Renier A, Descatha A, Hysi I, AbdAlsamad I, Billon-Galland MA, Blons H, Clin B, Danel C, Debrosse D, Galateau-Salle F, Housset B, et al. Differential mutation profiles and similar intronic TP53 polymorphisms in asbestos-related lung cancer and pleural mesothelioma. Mutagenesis. 2013;28(3):323-31.

77. Guo Y, Chirieac LR, Bueno R, Pass H, Wu W, Malinowska IA, Kwiatkowski DJ. Tsc1-Tp53 loss induces mesothelioma in mice, and evidence for this mechanism in human mesothelioma. Oncogene. 2014;33(24):3151-60.
78. Dar AA, Belkhiri A, El-Rifai W. The aurora kinase A regulates GSK-3 [beta] in gastric cancer cells. Oncogene. 2008;28(6):866-75.

79. McWilliams RR, Wieben ED, Rabe KG, Pedersen KS, Wu Y, Sicotte H, Petersen GM. Prevalence of CDKN2A mutations in pancreatic cancer patients: implications for genetic counseling. Eur J Hum Genet. 2011;19(4):472-8.

80. Di Fiore R, D'Anneo A, Tesoriere G, Vento R. RB1 in cancer: Different mechanisms of RB1 inactivation and alterations of $\mathrm{pRb}$ pathway in tumorigenesis. Journal of Cellular Physiology. 2013;228(8):1676-87.

81. Neuhausen S, Brummel S, Ding Y, Singer C, Pfeiler G, Lynch H, Nathanson K, Rebbeck T, Garber J, Couch F, Weitzel J, Narod S, Ganz P, et al. Genetic variation in insulin-like growth factor signaling genes and breast cancer risk among BRCA1 and BRCA2 carriers. Breast Cancer Research. 2009;11(5):R76.

82. Musgrove EA, Caldon CE, Barraclough J, Stone A, Sutherland RL. Cyclin D as a therapeutic target in cancer. Nat Rev Cancer. 2011;11(8):558-72.

83. Bueno R, Stawiski EW, Goldstein LD, Durinck S, De Rienzo A, Modrusan Z, Gnad F, Nguyen TT, Jaiswal BS, Chirieac LR, Sciaranghella D, Dao N, Gustafson CE, et al. Comprehensive genomic analysis of malignant pleural mesothelioma identifies recurrent mutations, gene fusions and splicing alterations. Nat Genet. 2016; advance online publication.

84. Stoimenov I, Helleday T. PCNA on the crossroad of cancer. Biochemical Society transactions. 2009;37(Pt 3):605-13.

85. Brown JM. Tumor Hypoxia in Cancer Therapy. In: Helmut $\mathrm{S}$, Bernhard B, editors. Methods in enzymology. Volume 435: Academic Press; 2007. p. 295-321.

86. Kulshreshtha R, Davuluri RV, Calin GA, Ivan M. A microRNA component of the hypoxic response. Cell Death Differ. 2008;15(4):667-71.

87. Ravenna L, Cardillo I, Curzio G, Baldi A, Mattioni M. Mesothelioma and Hypoxia: Modulation of the Inflammation-Related Phenotype and Identification of Prognostic Markers. J Cancer Sci Ther. 2014;6:378-87.

88. Wilson WR, Hay MP. Targeting hypoxia in cancer therapy. Nat Rev Cancer. 2011;11(6):393-410.

89. Klabatsa A, Chicklore S, Barrington SF, Goh V, LangLazdunski L, Cook GJ. The association of 18F-FDG PET/CT parameters with survival in malignant pleural mesothelioma. European journal of nuclear medicine and molecular imaging. 2014;41(2):276-82.

90. Ghattass K, Assah R, El-Sabban M, Gali-Muhtasib H. Targeting hypoxia for sensitization of tumors to radio- and chemotherapy. Current cancer drug targets. 2013;13(6):67085.

91. Yang C, Jiang L, Zhang H, Shimoda LA, DeBerardinis RJ, Semenza GL. Analysis of hypoxia-induced metabolic reprogramming. Methods in enzymology. 2014;542:425-55.

92. Johnston SC, Larsen $\mathrm{CN}$, Cook WJ, Wilkinson KD, 
Hill CP. Crystal structure of a deubiquitinating enzyme (human UCH-L3) at 1.8 å resolution. The EMBO Journal. 1997;16(13):3787-96.

93. Kaira K, Serizawa M, Koh Y, Takahashi T, Hanaoka H, Oriuchi N, Endo M, Kondo H, Nakajima T, Yamamoto N. Relationship between 18F-FDG uptake on positron emission tomography and molecular biology in malignant pleural mesothelioma. European Journal of Cancer. 2012;48(8):1244-54.

94. Dengler VL, Galbraith M, Espinosa JM. Transcriptional Regulation by Hypoxia Inducible Factors. Critical reviews in biochemistry and molecular biology. 2014;49(1):1-15.

95. Kaira K, Oriuchi N, Takahashi T, Nakagawa K, Ohde Y, Okumura T, Murakami H, Shukuya T, Kenmotsu H, Naito T, Kanai Y, Endo M, Kondo H, et al. L-Type Amino Acid Transporter 1 (LAT1) Expression in malignant pleural mesothelioma. Anticancer Research. 2011;31(12):4075-82.

96. Klabatsa A, Sheaff MT, Steele JPC, Evans MT, Rudd RM, Fennell DA. Expression and prognostic significance of hypoxia-inducible factor 1alpha (HIF-1alpha) in malignant pleural mesothelioma (MPM). Lung cancer (Amsterdam, Netherlands). 2006;51(1):53-9.

97. Francis RJ, Segard T, Morandeau L, Lee YC, Millward MJ, Segal A, Nowak AK. Characterization of hypoxia in malignant pleural mesothelioma with FMISO PET-CT. Lung cancer (Amsterdam, Netherlands). 2015;90(1):55-60.

98. Matsuzaki S, Jardon K, Maleysson E, D’Arpiany F, Canis M, Bazin JE, Mage G. Carbon dioxide pneumoperitoneum, intraperitoneal pressure, and peritoneal tissue hypoxia: a mouse study with controlled respiratory support. Surgical endoscopy. 2010;24(11):2871-80.

99. Bristow RG, Hill RP. Hypoxia and metabolism: Hypoxia, DNA repair and genetic instability. Nat Rev Cancer. 2008;8(3):180-92.

100. Goudarzi H, Hida Y, Takano H, Teramae H, Iizasa H, Hamada J-i. Hypoxia affects in vitro growth of newly established cell lines from patients with malignant pleural mesothelioma. Biomedical Research. 2013;34(1):13-21.

101. Klabatsa A, Sheaff MT, Steele JP, Evans MT, Rudd RM, Fennell DA. Expression and prognostic significance of hypoxia-inducible factor 1alpha (HIF-1alpha) in malignant pleural mesothelioma (MPM). Lung cancer (Amsterdam, Netherlands). 2006;51(1):53-9.

102. Vander Heiden MG, Cantley LC, Thompson CB. Understanding the Warburg Effect: The Metabolic Requirements of Cell Proliferation. Science (New York, NY). 2009;324(5930):1029-33.

103. Manente AG, Valenti D, Pinton G, Jithesh PV, Daga A, Rossi L, Gray SG, O’Byrne KJ, Fennell DA, Vacca RA, Nilsson S, Mutti L, Moro L. Estrogen receptor [beta] activation impairs mitochondrial oxidative metabolism and affects malignant mesothelioma cell growth in vitro and in vivo. Oncogenesis. 2013;2:e72.

104. Guise CP, Mowday AM, Ashoorzadeh A, Yuan R, Lin W-H,
Wu D-H, Smaill JB, Patterson AV, Ding K. Bioreductive prodrugs as cancer therapeutics: targeting tumor hypoxia. Chinese Journal of Cancer. 2014;33(2):80-6.

105. Wang P, Jin X, Cai J, Chen J, Ji M. Recent advances in small molecule prodrugs for cancer therapy. Anti-cancer agents in medicinal chemistry. 2014;14(3):418-39.

106. Prabhu RH, Patravale VB, Joshi MD. Polymeric nanoparticles for targeted treatment in oncology: current insights. International Journal of Nanomedicine. 2015;10:1001-18.

107. Thambi T, Deepagan VG, Yoon HY, Han HS, Kim SH, Son S, Jo DG, Ahn CH, Suh YD, Kim K, Kwon IC, Lee DS, Park JH. Hypoxia-responsive polymeric nanoparticles for tumortargeted drug delivery. Biomaterials. 2014;35(5):1735-43.

108. McDonald PC, Winum J-Y, Supuran CT, Dedhar S. Recent Developments in Targeting Carbonic Anhydrase IX for Cancer Therapeutics. Oncotarget. 2012;3(1):84-97.

109. Hoskin PJ, Sibtain A, Daley FM, Wilson GD. GLUT1 and CAIX as intrinsic markers of hypoxia in bladder cancer: relationship with vascularity and proliferation as predictors of outcome of ARCON. Br J Cancer. 2003;89(7):1290-7.

110. Vaupel P, Mayer A. Hypoxia in cancer: significance and impact on clinical outcome. Cancer Metastasis Rev. 2007;26(2):225-39

111. Karroum O, Kengen J, Danhier P, Magat J, Mignion L, Bouzin C, Verrax J, Charette N, Starkel P, Calderon $\mathrm{PB}$, Sonveaux P, Feron O, Gregoire V, et al. Tumor reoxygenation following administration of MitogenActivated Protein Kinase inhibitors: a rationale for combination with radiation therapy. Radiotherapy and oncology : journal of the European Society for Therapeutic Radiology and Oncology. 2012;105(1):64-71.

112. Clement JJ, Tanaka N, Song CW. Tumor Reoxygenation and Postirradiation Vascular Changes. Radiology. 1978;127(3):799-803.

113. Koopmans AE, Verdijk RM, Brouwer RWW, van den Bosch TPP, van den Berg MMP, Vaarwater J, Kockx CEM, Paridaens D, Naus NC, Nellist M, van Ijcken WFJ, Kilic E, de Klein A. Clinical significance of immunohistochemistry for detection of BAP1 mutations in uveal melanoma. Mod Pathol. 2014;27(10):1321-30.

114. Joseph RW, Kapur P, Serie DJ, Parasramka M, Ho TH, Cheville JC, Frenkel E, Parker AS, Brugarolas J. Clear Cell Renal Cell Carcinoma Subtypes Identified by BAP1 and PBRM1 Expression. The Journal of Urology. 2016;195(1):180-7.

115. Capkova L, Koubkova L, Kodet R. Expression of carbonic anhydrase IX (CAIX) in malignant mesothelioma. An immunohistochemical and immunocytochemical study. Neoplasma. 2014;61(2):161-9.

116. Carbone M, Yang H, Pass HI, Krausz T, Testa JR, Gaudino G. BAP1 and cancer. Nat Rev Cancer. 2013;13(3):153-9.

117. Luoto KR, Kumareswaran R, Bristow RG. Tumor hypoxia as a driving force in genetic instability. Genome Integrity. 
2013;4:5-

118. Parks SK, Chiche J, Pouyssegur J. Disrupting proton dynamics and energy metabolism for cancer therapy. Nat Rev Cancer. 2013;13(9):611-23.

119. Didier Jean, Julien Daubriac, Françoise Le Pimpec-Barthes, Françoise Galateau-Salle, Marie-Claude Jaurand. Molecular Changes in Mesothelioma With an Impact on Prognosis and Treatment. Archives of Pathology \& Laboratory Medicine. 2012;136(3):277-93

120. Colla S, Storti P, Donofrio G, Todoerti K, Bolzoni M, Lazzaretti M, Abeltino M, Ippolito L, Neri A, Ribatti D, Rizzoli V, Martella E, Giuliani N. Low bone marrow oxygen tension and hypoxia-inducible factor-1 alpha overexpression characterize patients with multiple myeloma: role on the transcriptional and proangiogenic profiles of CD138(+) cells. Leukemia. 2010;24(11):1967-70.

121. Bristow RG, Hill RP. Hypoxia and metabolism. Hypoxia, DNA repair and genetic instability. Nat Rev Cancer. 2008;8(3):180-92.

122. Hirschhaeuser F, Sattler UG, Mueller-Klieser W. Lactate: a metabolic key player in cancer. Cancer Res. 2011;71(22):6921-5.

123. Ruan GX, Kazlauskas A. Axl is essential for VEGFA-dependent activation of PI3K/Akt. EMBO J. 2012;31(7):1692-703.

124. Tabernero J. The role of VEGF and EGFR inhibition: implications for combining anti-VEGF and anti-EGFR agents. Molecular cancer research : MCR. 2007;5(3):20320.

125. Awazu Y, Nakamura K, Mizutani A, Kakoi Y, Iwata H, Yamasaki S, Miyamoto N, Imamura S, Miki H, Hori A. A novel inhibitor of c-Met and VEGF receptor tyrosine kinases with a broad spectrum of in vivo antitumor activities. Molecular cancer therapeutics. 2013;12(6):91324.

126. Ou WB, Corson JM, Flynn DL, Lu WP, Wise SC, Bueno R, Sugarbaker DJ, Fletcher JA. AXL regulates mesothelioma proliferation and invasiveness. Oncogene. 2011;30(14):1643-52.

127. Zhou S, Liu L, Li H, Eilers G, Kuang Y, Shi S, Yan Z, Li X, Corson JM, Meng F, Zhou H, Sheng Q, Fletcher JA, et al. Multipoint targeting of the PI3K/mTOR pathway in mesothelioma. Br J Cancer. 2014;110(10):2479-88.

128. Zhang J, Yang PL, Gray NS. Targeting cancer with small molecule kinase inhibitors. Nat Rev Cancer. 2009;9(1):2839.

129. Ahmadi M, Ahmadihosseini Z, Allison SJ, Begum S, Rockley K, Sadiq M, Chintamaneni S, Lokwani R, Hughes N, Phillips RM. Hypoxia modulates the activity of a series of clinically approved tyrosine kinase inhibitors. British Journal of Pharmacology. 2014;171(1):224-36.

130. Ranpura V, Hapani S, Wu S. Treatment-related mortality with bevacizumab in cancer patients: a meta-analysis. Jama. 2011;305(5):487-94.
131. Kindler HL, Karrison TG, Gandara DR, Lu C, Krug LM, Stevenson JP, Janne PA, Quinn DI, Koczywas MN, Brahmer JR, Albain KS, Taber DA, Armato SG, 3rd, et al. Multicenter, double-blind, placebo-controlled, randomized phase II trial of gemcitabine/cisplatin plus bevacizumab or placebo in patients with malignant mesothelioma. Journal of clinical oncology : official journal of the American Society of Clinical Oncology. 2012;30(20):2509-15.

132. Green SL, Freiberg RA, Giaccia AJ. p21(Cip1) and p27(Kip1) Regulate Cell Cycle Reentry after Hypoxic Stress but Are Not Necessary for Hypoxia-Induced Arrest. Molecular and Cellular Biology. 2001;21(4):1196-206.

133. Stahel RA, Riesterer O, Xyrafas A, Opitz I, Beyeler M, Ochsenbein A, Früh M, Cathomas R, Nackaerts K, Peters S, Mamot C, Zippelius A, Mordasini C, et al. Neoadjuvant chemotherapy and extrapleural pneumonectomy of malignant pleural mesothelioma with or without hemithoracic radiotherapy (SAKK 17/04): a randomised, international, multicentre phase 2 trial. The Lancet Oncology.16(16):1651-8.

134. Rapisarda A, Hollingshead M, Uranchimeg B, Bonomi CA, Borgel SD, Carter JP, Gehrs B, Raffeld M, Kinders RJ, Parchment R, Anver MR, Shoemaker RH, Melillo G. Increased antitumor activity of bevacizumab in combination with hypoxia inducible factor-1 inhibition. Molecular cancer therapeutics. 2009;8(7):1867-77.

135. Bindra RS, Vasselli JR, Stearman R, Linehan WM, Klausner RD. VHL-mediated hypoxia regulation of cyclin D1 in renal carcinoma cells. Cancer Res. 2002;62(11):3014-9.

136. Ou W.B, Carson JM, Flynn DL, Lu WP, Wise SC, Beuno R, Sugarbaker DJ, Fletcher JA. AXL regulates mesothelioma proliferation and invasiveness. Oncogene. 2011; 30(14): 1643-1652.

137. Wouters BG, Koritzinsky M. Hypoxia signalling through mTOR and the unfolded protein response in cancer. Nat Rev Cancer. 2008;8(11):851-64.

138. Cacciotti P, Barbone D, Porta C, Altomare DA, Testa JR, Mutti L, Gaudino G. SV40-Dependent AKT Activity Drives Mesothelial Cell Transformation after Asbestos Exposure. Cancer Research. 2005;65(12):5256-62.

139. Cacciotti P, Barbone D, Porta C, Altomare DA, Testa JR, Mutti L, Gaudino G. SV40-dependent AKT activity drives mesothelial cell transformation after asbestos exposure. Cancer Res. 2005;65(12):5256-62.

140. Pinton G, Manente AG, Angeli G, Mutti L, Moro L. Perifosine as a Potential Novel Anti-Cancer Agent Inhibits EGFR/MET-AKT Axis in Malignant Pleural Mesothelioma. PLoS ONE. 2012;7(5):e36856.

141. Agarwal V, Campbell A, Beaumont K, Cawkwell L, Lind M. PTEN protein expression in malignant pleural mesothelioma. Tumor Biol. 2013;34(2):847-51.

142. Sheridan C. First Axl inhibitor enters clinical trials. Nat Biotech. 2013;31(9):775-6.

143. Carbone M, Ferris L, Baumann F, Napolitano A, Lum C, 
Flores E, Gaudino G, Powers A, Bryant-Greenwood P, Krausz T, Hyjek E, Tate R, Friedberg J, et al. BAP1 cancer syndrome: malignant mesothelioma, uveal and cutaneous melanoma, and MBAITs. Journal of Translational Medicine. 2012;10(1):179.

144. Misaghi S, Ottosen S, Izrael-Tomasevic A, Arnott D, Lamkanfi M, Lee J, Liu J, O'Rourke K, Dixit VM, Wilson AC. Association of C-Terminal Ubiquitin Hydrolase BRCA1-Associated Protein 1 with Cell Cycle Regulator Host Cell Factor 1. Molecular and Cellular Biology. 2009;29(8):2181-92.

145. Guo G, Chmielecki J, Goparaju C, Heguy A, Dolgalev I, Carbone M, Seepo S, Meyerson M, Pass HI. Wholeexome sequencing reveals frequent genetic alterations in BAP1, NF2, CDKN2A, and CUL1 in malignant pleural mesothelioma. Cancer Res. 2015;75(2):264-9.

146. Green SL, Freiberg RA, Giaccia AJ. p21Cip1 and p27Kip1Regulate Cell Cycle Reentry after Hypoxic Stress but Are Not Necessary for Hypoxia-Induced Arrest. Molecular and Cellular Biology. 2001;21(4):1196-206.

147. Chung CTS, Santos GDC, Hwang DM, Ludkovski O, Pintilie M, Squire JA, Tsao M-S. FISH assay development for the detection of p16/CDKN2A deletion in malignant pleural mesothelioma. Journal of clinical pathology. 2010;63(7):630-4.

148. Murakami H, Mizuno T, Taniguchi T, Fujii M, Ishiguro F, Fukui T, Akatsuka S, Horio Y, Hida T, Kondo Y, Toyokuni S, Osada H, Sekido Y. LATS2 Is a Tumor Suppressor Gene of Malignant Mesothelioma. Cancer Research. 2011;71(3):873.

149. Ma B, Chen Y, Chen L, Cheng H, Mu C, Li J, Gao R, Zhou C, Cao L, Liu J, Zhu Y, Chen Q, Wu S. Hypoxia regulates Hippo signalling through the SIAH2 ubiquitin E3 ligase. Nat Cell Biol. 2015;17(1):95-103.

150. Huang X, Le Q-T, Giaccia AJ. MiR-210 - micromanager of the hypoxia pathway. Trends in Molecular Medicine. 2010;16(5):230-7.

151. Bindra RS, Glazer PM. Repression of RAD51 gene expression by E2F4//p130 complexes in hypoxia. Oncogene. 2006;26(14):2048-57.

152. Olcina M, Lecane PS, Hammond EM. Targeting Hypoxic Cells through the DNA Damage Response. Clinical Cancer Research. 2010;16(23):5624-9.

153. Walter RFH, Vollbrecht C, Werner R, Mairinger $T$, Schmeller J, Flom E, Wohlschlaeger J, Barbetakis N, Paliouras D, Chatzinikolaou F, Adamidis V, Tsakiridis K, Zarogoulidis P, et al. Screening of Pleural Mesotheliomas for DNA-damage Repair Players by Digital Gene Expression Analysis Can Enhance Clinical Management of Patients Receiving Platin-Based Chemotherapy. Journal of Cancer. 2016;7(13):1915-25.

154. Ak G, Tomaszek SC, Kosari F, Metintas M, Jett JR, Metintas S, Yildirim H, Dundar E, Dong J, Aubry MC, Wigle DA, Thomas CF. MicroRNA and mRNA Features of Malignant Pleural Mesothelioma and Benign AsbestosRelated Pleural Effusion. BioMed Research International. 2015;2015:8.

155. Tomasetti M, Nocchi L, Staffolani S, Manzella N, Amati M, Goodwin J, Kluckova K, Nguyen M, Strafella E, Bajzikova M, Peterka M, Lettlova S, Truksa J, et al. MicroRNA-126 Suppresses Mesothelioma Malignancy by Targeting IRS1 and Interfering with the Mitochondrial Function. Antioxidants \& Redox Signaling. 2014;21(15):2109-25.

156. Reid G. MicroRNAs in mesothelioma: from tumour suppressors and biomarkers to therapeutic targets. Journal of Thoracic Disease. 2015;7(6):1031-40.

157. Gee GV, Koestler DC, Christensen BC, Sugarbaker DJ, Ugolini D, Ivaldi GP, Resnick MB, Houseman EA, Kelsey KT, Marsit CJ. Downregulated microRNAs in the differential diagnosis of malignant pleural mesothelioma. International journal of cancer Journal international du cancer. 2010;127(12):2859-69.

158. Benjamin H, Lebanony D, Rosenwald S, Cohen L, Gibori H, Barabash N, Ashkenazi K, Goren E, Meiri E, Morgenstern S, Perelman M, Barshack I, Goren Y, et al. A diagnostic assay based on microRNA expression accurately identifies malignant pleural mesothelioma. The Journal of molecular diagnostics : JMD. 2010;12(6):771-9.

159. Micolucci L, Akhtar MM, Olivieri F, Rippo MR, Procopio AD. Diagnostic value of microRNAs in asbestos exposure and malignant mesothelioma: systematic review and qualitative meta-analysis. Oncotarget. 2016;7(36).

160. Budhu A, Ji J, Wang X. The clinical potential of microRNAs. Journal of Hematology \& Oncology. 2010;3(1):37.

161. Chen Z, Lai T-C, Jan Y-H, Lin F-M, Wang W-C, Xiao H, Wang Y-T, Sun W, Cui X, Li Y-S, Fang T, Zhao H, Padmanabhan $\mathrm{C}$, et al. Hypoxia-responsive miRNAs target argonaute 1 to promote angiogenesis. The Journal of Clinical Investigation. 2013;123(3):1057-67.

162. Hu Y-L, DeLay M, Jahangiri A, Molinaro AM, Rose SD, Carbonell WS, Aghi MK. Hypoxia-Induced Autophagy Promotes Tumor Cell Survival and Adaptation to Antiangiogenic Treatment in Glioblastoma. Cancer Research. 2012;72(7):1773-83.

163. Wilkinson S, O’Prey J, Fricker M, Ryan KM. Hypoxiaselective macroautophagy and cell survival signaled by autocrine PDGFR activity. Genes \& Development. 2009;23(11):1283-8.

164. Wang M, Kaufman RJ. The impact of the endoplasmic reticulum protein-folding environment on cancer development. Nat Rev Cancer. 2014;14(9):581-97.

165. Rzymski T, Milani M, Pike L, Buffa F, Mellor HR, Winchester L, Pires I, Hammond E, Ragoussis I, Harris AL. Regulation of autophagy by ATF4 in response to severe hypoxia. Oncogene. 2010;29(31):4424-35.

166. Borczuk AC, Cappellini GCA, Kim HK, Hesdorffer M, Taub RN, Powell CA. Molecular profiling of malignant 
peritoneal mesothelioma identifies the ubiquitin-proteasome pathway as a therapeutic target in poor prognosis tumors. Oncogene. 2006;26(4):610-7.

167. Wali A, Wang Y, Kanakapalli D, Liu Z, Sharma S, Lonardo F, Rishi A, Majumdar A, Ping Dou Q, Carbone M, Ruckdeschel J, Pass H. Role of Ubiquitin-proteasome proteolytic pathway in malignant pleural mesothelioma. Cancer Research. 2007;67(9 Supplement):4406.

168. Ruosaari S, Hienonen-Kempas T, Puustinen A, Sarhadi VK, Hollmén J, Knuutila S, Saharinen J, Wikman H, Anttila $\mathrm{S}$. Pathways affected by asbestos exposure in normal and tumour tissue of lung cancer patients. BMC Medical Genomics. 2008;1:55-.

169. Yang Y-L, Ni J, Hsu P-C, Mao J-H, Hsieh D, Xu A, Chan G, Au A, Xu Z, Jablons DM, You L. Cul4A overexpression associated with Gli1 expression in malignant pleural mesothelioma. Journal of Cellular and Molecular Medicine. 2015;19(10):2385-96.

170. Yuan B-Z, Chapman JA, Reynolds SH. Proteasome Inhibitor MG132 Induces Apoptosis and Inhibits Invasion of Human Malignant Pleural Mesothelioma Cells. Translational Oncology. 2008;1(3):129-40.

171. Sun X, Gulyás M, Hjerpe A, Dobra K. Proteasome inhibitor PSI induces apoptosis in human mesothelioma cells. Cancer letters. 2006;232(2):161-9.

172. O`Brien ME, Gaafar RM, Popat S, Grossi F, Price A, Talbot DC, Cufer T, Ottensmeier C, Danson S, Pallis A, Hasan B, Van Meerbeeck JP, Baas P. Phase II study of first-line bortezomib and cisplatin in malignant pleural mesothelioma and prospective validation of progression free survival rate as a primary end-point for mesothelioma clinical trials (European Organisation for Research and Treatment of Cancer 08052). European journal of cancer (Oxford, England : 1990). 2013;49(13):2815-22.

173. Trédan O, Galmarini CM, Patel K, Tannock IF. Drug Resistance and the Solid Tumor Microenvironment. Journal of the National Cancer Institute. 2007;99(19):1441-54. 